\title{
KONTEKSTUALISASI FIKIH MELALUI PRINSIP KEMASLAHATAN
}

\author{
Ansori*
}

\begin{abstract}
The existence of Islamic law (figh) wich is able to improve the society condition and to solve many problems is such a fact. Contextualize needs to be done continuously and one of the guidance is goodness principal.
\end{abstract}

Kata Kunci: kemaslahatan, kontekstualisasi, fikih.

\section{A. Pendahuluan}

Fikih, demikian dikatakan oleh S. Waqar Ahmed Husaini, merupakan hasil penalaran terhadap syari'at yang ada dalam al-Qur'an dan al-Sunnah; ${ }^{1}$ atau menurut Abdurrahman Wahid fikih adalah hukum-hukum operasional dari ketentuan yang dirumuskan dalam bentuk pedoman umum yakni syari'at. ${ }^{2}$ Di samping mengatur hubungan antara manusia dengan Tuhan (fikih ibadah) fikih juga

* Penulis adalah dosen tetap Jurusan Syari'ah STAIN Purwokerto dalam bidang Fiqh. Alumni IAIN Sunan Kalijaga Yogyakarta (S.1) dan IAIN Sulthan Syarif Qasim (S.2).

'S. Waqar Ahamad Husani, The Early Development of Islamic Jurisprudence, terj. Agah Ganardi, cet. 1. (Bandung: Pustaka, 1984), hal. 45.

${ }^{2}$ Abdurrahman Wahid, "Pengembangan Fiqh yang Kontekstual," Pesantren, 2, 2 (1985), hal. 7. 


\section{Ansori}

mengatur masalah-masalah kemasyarakatan (fikih mu'amalat, munakahat, jinayat, siyasah dan sebagainya). Pembahasan dalam tulisan ini, lebih dititikberatkan kepada fikih dalam bidang yang kedua.

Syari'at Islam dalam memandang masalah-masalah yang mengatur hubungan manusia dengan Tuhan (akidah dan ibadah) berbeda dengan pandangannya terhadap masalah-masalah kemasyarakatan. Titik tolak perbedaan itu berangkat dari suatu kenyataan bahwa masalah-masalah kemasyarakatan tidak akan berhenti, bahkan akan terus berkembang seiring dengan perkembangan masyarakat itu sendiri. Karena itu, dalam bidang kemasyarakatan, yang mengatur hubungan sesama manusia, syari'at Islam bersikap luwes, hanya meletakkan garis-garis besarnya saja. Apabila muncul peristiwa atau problem baru, maka akallah yang diberi wewenang untuk menyelesaikannya. Namun demikian, syari'at Islam memberikan prinsip-prinsip pokok yang harus dijadikan dasar pertimbangan dalam melahirkan kebijakan atau keputusan fikih. Prinsip pokok tersebut antara lain adalah kemaslahatan.

Prinsip kemaslahatan inilah yang mendasari al-Qur'an (sebagai budan li al-nass) dan al-sunnah sebagai sumber syari'at Islam, sehingga dapat dijabarkan menjadi keputusan fikih yang bisa diterapkan dalam setiap masa, tempat, kondisi dan situasi. Mengapa prinsip pokok (dasar) yang harus dipegangi itu adalah kemaslahatan? Inilah yang akan diuraikan dalam tulisan ini.

\section{A. Metode-Metode Penetapan Fikih}

Fikih secara harfiah berarti "memahami” (faham) atau "mengerti". Sedangkan menurut istilah fikih — sebagaimana yang telah disinggung di depan — ialah memahami syari'at yang termuat dalam al-Qur'an dan al-Sunnah dengan menggunakan akal dan metode tertentu. Berangkat dari pengertian tersebut, ketentuanketentuan yang sudah tegas, jelas, dan rinci serta operasional adalah syari'ah. Sedangkan ketentuan-ketentuan hukum yang merupakan hasil intepretasi dan penjabaran dari nas yang sifatnya belum tegas,

Al Manāhij, Vol. 2 No. 1 Januari - Juni 2008 
jela, dan masih global adalah fikih. Perbedaan pengertian kedua istilah ini, fikih dan syari'at, penting untuk ditekankan karena akan menjadi pijakan pembahasan selanjutnya dalam tulisan ini. Terutama karena istilah fikih akan sering digunakan dalam tulisan ini.

Ada beberapa metode yang diterapkan oleh para fukaha (mujtahid) dalam menetapkan hukum-hukum fikih, meskipun tidak secara keseluruhannya disepakati, yakni: qiyas, istiḥsān, 'urf (adat), dan istislăh (maslahah mursalab). Empat metode tersebut merupakan metode yang sarat dengan muatan nilai kontekstualitasnya dan yang disebutkan terakhir adalah yang menjadi fokus dalam pembahasan ini.

\section{Qiyas}

Qiyas di kalangan ulama usul fikih ialah didefinisikan sebagai "menetapkan suatu kebijakan hukum (fikih) dengan cara menyamakan antara kejadian yang baru yang tidak ada nasnya dengan kejadian yang sudah ada nas atau ketentuan hukumnya, karena adanya persamaan illah (motif hukum)."3 Contoh popularnya adalah pengqiyasan beberapa jenis minuman keras yang ada sekarang ini dengan khamr. Ketentuan hukum dari jenis-jenis minuman yang beraneka ragam sekarang ini secara tegas (teks) tidak ada dalam nas. Maka kemudian hukumnya dipersamakan (haram) dengan khamr yang sudah secara tegas disebutkan dalam al-Qur'an, karena adanya persamaan 'illah yaitu memabukkan, merusak akal.

Dari contoh tersebut, bisa diambil pengertian bahwa prinsip yang ada pada metode qiyas merupakan metode yang bisa untuk mengatasi atau memecahkan masalah-masalah baru yang muncul ditengah-tengah masyarakat yang ketentuan hukumnya tidak secara langsung disebutkan dalam nas (al-qur'an atau al-sunnah). Dengan demikian, fikih tidak hanya merupakan satu keputusan hukum dari penjabaran nas yang sudah baku dan hasil pemahaman yang terbatas

${ }^{3}$ Abdul Wahab Khallaf, Ilmu Usul Fiqh, terj. Nur Iskandar Albarsany, cet. 2, (Bandung: Risalah, 1985), hal. 73. 


\section{Ansori}

pada masanya, akan tetapi merupakan suatu keputusan hukum yang mungkin berubah dan berkembang sesuai dengan keadaan yang dihadapi.

\section{Istihsān}

Secara bahasa, istị̣sān berarti menganggap baik terhadap sesuatu. ${ }^{4}$ Dari pengertian dasar ini, Jalaluddin Rahmat menguraikan lebih luas tentang prinsip-prinsip yang ada pada metode istibsă , antara lain bahwa istiḩsān adalah menetapkan suatu kebijakan hukum tertentu dengan petimbangan sesuatu yang dianggap baik, secara akal maupun 'urf (pada umumnya). ${ }^{5}$

Selanjutnya ia mengemukakan satu contoh tentang kebijakan hukum yang berpijak dari prinsip yang ada pada metode ini, yaitu tentang dibentuknya lembaga yang menyelesaikan urusan-urusan orang-orang yang diperlakukan tidak adil dikalangan budaya masyarakat Persia. Kemudian lembaga ini dikukuhkan oleh Dinasti Umayyah dengan nama Dewan Mazălim, karena menganggap hal itu adalah suatu kebaikan, walaupun tidak terdapat dalam al-Qur'an ataupun al-sunnah. ${ }^{6}$

Dari contoh tersebut, bisa dilihat bahwa dengan prinsip yang ada pada metode istihsān, keputusan fikih akan selalu berkembang dan bisa diterapkan sesuai dengan konteks yang ada. Lebih jauh, Husaini mengemukakan, bahwa prinsip yang ada pada metode istibsān adalah sebagai salah satu metode yang mampu digunakan untuk menyesuaikan keputusan-keputusan hukum (fikih) dengan kebutuhan-kebutuhan kontemporer masyarakat. ${ }^{7}$

\section{3. 'Urf (adat)}

Ulama usul fikih memaknai 'urf sebagai sesuatu yang telah dikenal oleh masyarakat dan merupakan kebiasaan dikalangan

${ }^{4}$ Ibid., hal. 118.

5 Jalaluddin Rahmat, "Peranan Tuntunan Situasi Dalam Memahami Hukum Islam," dalam Kontekstualisasi Doktrin Islam dalam Sejarah, cet. 1 (Jakarta: Paramadina, 1995), hal. 359 .

${ }^{6} \mathrm{Ibid}$

${ }^{7}$ Husaini, The Early Development, hal. 71.

Al Manāhij, Vol. 2 No. 1 Januari - Juni 2008 
mereka yang dianggap baik. ${ }^{8}$ Urf yang dapat dijadikan sebagai prinsip dalam penetapan hukum fikih adalah 'urf yang tidak bertentangan dengan prinsip-prinsip yang ada pada nas, yang dalam istilah usul fikih disebut dengan istilah 'urf sabih. Sedangkan 'urf yang bertentangan dengan prinsip-prinsip yang ada pada nas, yakni 'urf fásid, tidak dibenarkan untuk dijadikan dasar dalam penetapan hukum fikih.

Perhatian Islam terhadap 'urf (adat) ini bisa dilihat dalam sejarah, di mana Nabi Muhammad telah menyerap aneka ragam adat, kebiasaan dan konvensi-konvensi dari masa sebelum al-Qur'an diwahyukan, ke dalam kultur Islam, kemudian disempurnakan dan ditetapkan menjadi suatu ketentuan hukum dalam syari'at Islam. Misalnya tentang hukum żibār (Q.S. al-Mujadilah: 2-4) dan î̀a' (Q.S. al-Baqarah: 226), keduanya merupakan ketentuan hukum dalam syari'at Islam yang berasal dari 'urf atau adat istiadat bangsa Arab sebelumnya.

Atas dasar prinsip 'urf inilah para ahli usul membuat suatu kaidah umum yang berbunyi al-'adah mubakkamah, yang berarti adat kebiasaan dapat dijadikan dasar penetapan hukum/fikih. Kaidah tersebut menggariskan, bahwa kondisi lingkungan sosial atau adat kebiasaan suatu masyarakat adalah faktor yang harus dipertimbangkan dalam setiap menetapkan suatu kebijakan hukum. Terutama hukum-hukum yang berkenaan dengan masalah-masalah yang mengatur antar sesama manusia dalam kehidupan keduniaan mereka (bukan masalah ibadah murni). Hal ini bisa dilihat pada suatu peristiwa di mana pada suatu hari Nabi mempertanyakan perilaku para petani yang membantu penyerbukan pohon kurma. Pada akhirnya beliau menyadari bahwa kritknya itu justru berakibat pada menurunnya panen kurma sehingga beliau menyatakan: "Saya ini adalah manusia biasa, jika saya menyuruhmu melakukan sesuatu yang berkaitan dengan agamamu, maka laksanakan. Tetapi jika saya

${ }^{8}$ Abdul Wahab Khallaf, Ilmu Usul Fiqh, terj. Nur Iskandar Albarsany, cet. II., Risalah, Bandung, 1985, hal. 132. 


\section{Ansori}

mengatakan suatu yang berkaitan dengan urusan dunia, maka sebenarnya itu hanya pendapat saya. Kamu lebih tahu dengan halhal yang berkaitan dengan urusan duniamu."

Dari sabda Nabi tersebut dapat disimpulkan bahwa kita diberi kewenangan untuk menetapkan suatu kebijakan hukum (fikih) dengan pertimbangan sesuatu yang paling baik dan relevan, yang tentunya terkait dengan unsur waktu, tempat, adat, dan kebudayaan. Hal ini dikuatkan oleh Husaini yang menyatakan bahwa keputusan didalam fikih sangat dipengaruhi oleh lingkungan sosial, material, dan intelektual dari setiap zaman dan masyarakat. ${ }^{9}$

Keputusan-keputusan fikih merupakan perincian-perincian kasus dari situasi di mana syari'at (al-Qur'an dan al-sunnah) hanya memberikan prinsip-prinsip pokok tanpa penjelasan detailnya. ${ }^{10}$ Dengan kata lain, fikih adalah merupakan hukum yang sifatnya kasuistik yaitu keputusan yang didasarkan atas pertimbangan kasuskasus tertentu yang terkait oleh tempat, situasi, kondisi, dan adat dari suatu masyarakat.

Perbedaan mengenai wali mujbir antara ulama Hanafiyah dan ulama Syafi'iyah adalah salah satu contoh bahwa fikih merupakan refleksi dari kondisi sosial (adat) masyarakat tertentu. Begitu pula munculnya qawl qadim dan qawl jadid-nya Imam Syafi'i. Dengan prinsip yang ada pada metode 'urf ini, fikih akan bisa berjalan seiring dengan dinamika masyarakat yang ada dan selalu bisa diterapkan dalam situasi dan kondisi masyarakat yang beragam latar belakang adat dan kebudayaannya.

\section{B. Kemaslahatan Sebagai Ruh Kontekstualisasi Fikih}

Dari berbagai literatur, ada beberapa istilah teknis yang memuat makna kemaslahatan, yaitu: istịlāh, maslaḥah mursalah, almaslabah al'ammah, yang oleh para penulis Indonesia umunya diartikan sebagai kemaslahatan atau kemaslahatan umum. Selanjutnya penulis

${ }^{9}$ Husaini, The Early Development, hal. 45. 
menggunakan istislāh sebagai istilah teknisnya dan istilah kemaslahatan dalam bahasa Indonesianya.

Sebagaimana yang telah disinggung di depan, bahwa prinsip yang ada pada metode istislă in ini adalah merupakan fokus dalam tulisan ini. Oleh karena itu prinsip metode ini akan dibahas sedikit lebih rinci dibanding dari metode lainnya yang telah diuraikan di depan.

\section{Pengertian Istiṣlāh}

Beberapa pengertian yang diambil dari sejumlah referensi mengenai istislăh adalah sebagai berikut:

a. Istișlāh ialah suatu kemaslahatan yang tidak ditetapkan oleh syara', tidak ada ketentuan untuk mewujudkannya dan tidak ada dalil yang melarangnya. ${ }^{11}$

b. Istișlăh ialah suatu kebaikan yang tidak terikat pada dalil/nas (al-Qur'an dan al-sunnah). ${ }^{12}$

c. Istislặ ialah memperhatikan kesejahteraan umum atau kepentingan bersama yang tidak ditentukan oleh teks-teks al-qur'an dan al-sunnah. ${ }^{13}$

Dari beberapa pengertian yang dikemukakan di atas, dapat diambil suatu pengertian umum bahwa istisläh\} ialah menetapkan suatu ketentuan hukum fikih yang tidak ada di dalam al-Qur'an atau al-sunnah dengan cara mempertimbangkan kemaslahatan (kebaikan).

\section{Dasar Hukum Istiṣlāh}

a. Al-Qur'an

Allah menciptakan manusia di bumi ini tidak untuk berbuat kerusakan, akan tetapi supaya saling tolong menolong antara sesamanya, berbuat baik dan mencegah kemungkaran (Q.S. al-Maidah: 2, dan Q.S. al-A'raf: 157), sehingga kehidupan yang damai, sejahtera, tenteram, dan maslahat — sebagai salah satu sisi tujuan syari'at Islam — dapat terwujud. Terkait 
dengan ini, Allah menegaskan dalam firmannya: "Dan Kami tidak mengutus engkau (Muhammad) melainkan untuk (menjadi) rahmat bagi seluruh alam" (Q.S. al-Anbiya': 107). Ayat tersebut menunjukkan bahwa diutusnya Nabi Muhammad dengan semua misi yang diembannya adalah sebagai rahmat dan untuk mewujudkan kesejahteraan manusia secara keseluruhan. Aspek hukum, sebagai salah satu aspek dari risalah yang dibawanya, adalah juga untuk mewujudkan rạ̣mah li al-älamin di mana ia harus bertumpu kepada kemaslahatan umat manusia.

Ayat-ayat tersebut kiranya cukup sebagai landasan bahwa kebijakan-kebijakan dalam bidang hukum fikih mesti memperhatikan faktor kemaslahatan. Dengan mengabaikan nilai kemaslahatan berarti telah mengabaikan pula pesan syari'at Islam yang sangat mendasar, yakni mewujudkan rabmah li al-'alamin. ${ }^{14}$

\section{b. Al-Sunnah}

Dalam salah satu hadis Rasulullah bersabda: "Tidak boleh berbuat madharat (kepada diri sendiri) dan berbuat madharat (kepada orang lain)." Apa yang disampaikan oleh Nabi tersebut, menurut Muhammad Sa'id Ramadan, kendati singkat namun mempunyai makna yang dalam dan luas, yakni pesan bahwa tindakan dan perbuatan apapun, kebijakan dan keputusan siapapun dan sampai kapanpun tidak boleh

${ }^{10}$ Ibid., hal. 78.

${ }^{1}$ Khallaf, Ilmu Usul Figh, hal. 124; Mukhtar Yahya, Dasar-Dasar Pembinaan Hukum Islam, cet. 1 (Bandung: Al-Ma'arif, 1986), hal. 105; Departemen Agama RI, Usbul Fiqh Jakarta: Proyek Pembinaan Prasarana dan Sarana Perguruan Tinggi Agama Islam, 1986), hal. 146.

${ }^{12}$ Masjfuk Zuhdi, Pengantar Hukum Syariat, cet. 1 (Jakarta: Haji Masagung, 1987), hal. 146.

${ }^{13}$ Husaini, The Early Development, hal. 73.

${ }^{14}$ Muhammad Sa'id Ramadan, Dawabịt al-Mașlạah, cet. III., Bairut : Mu'assasah alRisalah, 1987, hal : 75. 
menimbulkan kerusakan, kesusahan dan kesengsaraan, bagi diri sendiri maupun orang lain. Dengan kata lain, kemaslahatan, baik individu maupun kemaslahatan umum (al-maslabạ al-ámmab) harus selalu diperhatikan dan dipertimbangkan. ${ }^{15}$

\section{Kemaslahatan dalam Penetapan Hukum Fikih}

Faruq Abu Zaid mengemukakan - sebagaimana yang dikemukakan oleh Husaini di depan - bahwa fikih merupakan suatu keputusan yang lahir sebagai reaksi dari berbagai persoalan dan sebagai jawaban atas tuntutan hidup masyarakat. ${ }^{16}$ Oleh karena itu setiap keputusan hukum fikih tidak bisa dilepaskan dari kondisi dan situasi yang ada. Sebagaimana dinyatakan oleh Yusuf al-Qardāwí bahwa ciri dan sekaligus keistimewaan fikih yaitu dimungkinkannya melakukan suatu pengembangan dan penyesuaian (kontekstualisasi) terhadapnya. ${ }^{17}$

Untuk merealisasikan karakteristik fikih yang demikian itu prinsip kemaslahatan tidak bisa dilepaskan, sebab kemaslahatan yang dituntut dan dialami oleh manusia sifatnya selalu dinamis, tidak ada batasannya. Apabila penetapan hukum fikih tidak didasarkan atas kemaslahatan, maka masalah baru dan tuntutan perkembangan akan terabaikan. Yang demikian ini tentunya tidak sesuai dengan konsep umum tentang universalitas hukum Islam dimana fikih adalah merupakan pengembangan dan penjabaran darinya.

Kemaslahatan sebagai prinsip yang mendasari suatu ketetapan hukum juga dikemukakan oleh al-Shātiḅ dalam al-Muwä́aqāt-nya di mana ia menyatakan bahwa syari'at Islam itu sesungguhnya tiada lain adalah hanya untuk kemaslahatan manusia di dunia dan akhirat. ${ }^{18}$

\footnotetext{
${ }^{15}$ Ibid., hal. 79 .

${ }^{16}$ Farouq Abu Zaid, al-Syari'ab al-Islamiyab Baina al-Mubafifidzin wa al-Mujaddidin, terj. H. Husein Muhammad, cet. 1 (Jakarta: P3M, 1980), hal. 5.

${ }^{17}$ Yusuf al-Qarḍawi, al-Fiqh al-Isläñ̄ Bayna al-Aṣalab wa al-Tajdid, cet. 1 (Bairut: tnp., 1986), hal. 19.

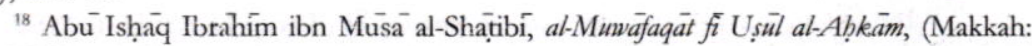
Där al-Baj, t.t.), hal. 6.
} 


\section{Ansori}

Hal yang senada dikemukakan pula oleh Izz al-Din ibn 'Abd al-Salām yang menyatakan bahwa semua bentuk pembebanan hukum adalah diperuntukkan demi kemaslahatan manusia, baik di dunia maupun di akhirat. ${ }^{19}$

Apa yang dikemukakan oleh dua ulama tersebut memberikan satu pengertian bahwa ketentuan-ketentuan hukum dalam Islam yang dibebankan kepada manusia, manfaatnya adalah untuk manusia itu sendiri, yaitu terwujudnya kemaslahatan (kebaikan) dalam hidup dan kehidupannya. Maka fikih sebagai pemahaman dan penjabaran atau turunan dari syari'at, dalam setiap keputusan dan kebijakan haruslah memperhatikan kemaslahatan umat manusia. Menurut Ibn al-Qayyim prinsip kemaslahatan merupakan faktor yang penting untuk diperhatikan agar setiap keputusan hukum dalam fikih mampu mewujudkan ketentraman dan kenyamanan bagi kehidupan manusia di mana hal ini merupakan tujuan utama dari syari'at Islam. ${ }^{20}$

Al-Shạtibí membagi kemaslahatan menjadi tiga bagian, yaitu:

a. Maslaḥah darüriyyah, yaitu kemaslahatan yang sifatnya sangat esensial dalam kehidupan manusia.

b. Mașlaḥah hajajiyyah, yaitu kemaslahatan yang sifatnya untuk menghilangkan atau menghindari kesulitan-kesulitan dalam kehidupan manusia.

c. Maslaḥah taḅsiniyyah, yaitu kemaslahatan yang sifatnya sebagai pelengkap dalam kehidupan manusia. ${ }^{21}$

Pembagian kemaslahatan tersebut menunjukkan bahwa ia merupakan kaktor urgen dalam menetapkan hukum fikih sehingga menjadikan fikih fleksibel untuk diterapkan dalam berbagai situasi yang berbeda-beda dalam kehidupan masyarakat yang bertingkattingkat, beragam, dan selalu mengalami perubahan dan perkembangan. Dengan memperhatikan kemaslahatan ini pula, menurut

19 'Izz al-Din ibn 'Abd al-Salām, Qavà'id al-Aḅkām fi Mașäli al-Anām (Beirut: Dār alMa'rifah, t.t.), hal. 63.

${ }^{20} \mathrm{Ibn}$ al-Qayyim al-Jawziyyah, Illäm al-Munaqqi iñ (Beirut: Där al-fil, t.t.), hal. 3.

${ }^{21}$ Al-Shätibi, al-Munāáăàt, hal. 9-11. 
Ziauddin Sardar, fikih mampu menghadapi dan memecahkan masalah-masalah yang muncul. ${ }^{22}$ Dalam kaitan ini Ahmad Azhar Basyir mengatakan: "Menetapkan ketentuan hukum (fikih) dengan berdasarkan kemaslahatan merupakan bidang yang amat subur untuk mengembangkan hukum Islam (fikih), khususnya dalam bidang mu'amalah kemasyarakatan." 23

Menurut Sardar kemaslahatan adalah suatu prinsip yang senantiasa tumbuh dan berkembang. Oleh karena itu, menurutnya, al-Qur'an dan al-sunnah sebagai dasar syari'at Islam tidak memuat ketentuan-ketentuan hukum tentang setiap kemungkinan yang dapat diramalkan. Al-Qur'an hanya memberikan batasan-batasan dan konsep-konsep global. ${ }^{24} \mathrm{Hal}$ ini menunjukkan bahwa untuk ketentuan-ketentuan hukum fikih yang dikeluarkan, dijabarkan, dan ditafsirkan daripadanya hendaknya disesuaikan dengan tuntutan masyarakat dan zaman melalui pertimbangan kemaslahatan tersebut.

Demikian pula dikemukakan oleh Nurcholis Majid bahwa kebijakan-kebijakan atau keputusan-keputusan Khalifah Umar Ibnu Khattab yang sepintas lalu menyimpang dari ketentuan yang ada pada nas pada dasarnya merupakan manifestasi dari penerapan prinsip kemaslahatan. ${ }^{25}$ Hal senada dikemukakan oleh Ali Yafie, bahwa setiap ketentuan hukum harus selalu memperhatikan kemaslahatan karena hal tersebut merupakan pesan dan tujuan sentral dari syari'at Islam. ${ }^{26}$

22 Sardar, Islamic Futures, hal. 126.

${ }^{23}$ Ahmad Azhar Basyir, "Pokok-Pokok Ijtihad Dalam Hukum Islam," dalam IJtihad dalam Sorotan, cet. 1 (Bandung: Mizan, 1988), hal. 50.

${ }^{24}$ Ziauddin Sardar, Islamic Futures The Shape of Ideeas to Come, terj. Rahmani Astuti, cet.1 (Bandung: Pustaka, 1985), hal. 115.

${ }^{25}$ Nurcholis Madjid, "Konsep Asbab al-Nuzul: Relevansinya bagi Pandangan Historisis Segi-Segi Tertentu Ajaran Keagamaan," dalam Kentekstualisasi Doktrin Islam dalam Sejarab, cet. 1 Jakarta: Paramadina, 1995), hal. 36.

${ }^{26}$ Ali Yafie, "Konsep-Konsep Istiḥsān, Istiṣlāh dan Maṣlaḥah al-'Āmmah," dalam: Kontekstualisasi Doktrin, hal : 365.

Al Manāhij, Vol. 2 No. 1 Januari - Juni 2008 


\section{Beberapa Contoh Ketetapan Fikih yang Didasarkan pada Prinsip Kemaslahatan}

Diantara para sahabat Nabi Umar bin Khattab merupakan salah seorang sahabat yang banyak meninggalkan lembaran-lembaran sejarah yang berkaitan dengan pemikiran dan kebijakan hukum Islam yang kreatif dan inovatif. Bahkan sebagai kalangan menyebutnya sebagai orang yang genius, kreatif, bijaksana dan mempunyai wawasan yang luas. Walaupun ada saja sebagian kalangan lain mengecamnya dikarenakan kebijakannya yang dinilai kontroversial.

Terlepas dari itu semua faktanya adalah bahwa pemikiran dan inovasi para fukaha sesudahnya, bahkan sampai sekarang, ${ }^{27}$ apakah itu upaya reaktualisasi, kontekstualisai, reinterpretasi, perubahan, penyesuaian, dan yang semacamnya - yang kesemuanya itu merupakan nilai dari dinamika hukum Islam - tidak lepas dari ide dan pemikiran serta kebijakan yang pernah dilakukan oleh khalifah Umar bin Khattab, atau setidaknya mengadopsi semangat yang mendasari pemikirannya tersebut. Di antara bentuk-bentuk ide, pemikiran, dan kebijakan Umar dapat dipandang sebagai inovasi dan kreasi baru adalah yang berkenaan dengan masalah-masalah sebagai berikut:

\section{a. Rampasan Perang}

Dalam Q.S. al-Anfal: 41 dinyatakan bahwa seperlima dari harta rampasan perang adalah untuk Allah, Rasul, kerabat Rasul, anak yatim, orang miskin dan ibnu sabil. Sedangkan yang sisanya (empatperlima), Rasul membagi-bagikan untuk tentara yang ikut berperang.

Pada waktu pemerintahan khalifah Umar, dimana beberapa wilayah telah berhasil ditaklukkan oleh tentaranya, ia tidak melaksanakan seperti yang dilaksanakan oleh Rasul yaitu membagi harta rampasan perang tersebut kepada prajurit yang

${ }^{27}$ Gagasan tentang reaktualisasi hukum Islam yang dikumandangkan Munawir Sjadzali pada akhir dekade 80 -an sebagian besarnya juga berpijak pada semangat pemikiran Umar ini. 
ikut berperang. Untuk mengetahui tindakan Umar dan alasan mengapa ia memutuskan demikian, ada baiknya dikutipkan di sini ucapan Umar dihadapan para tokoh pada saat itu:

Kalian telah mendengar pembicaraan mereka, kelompok yang menuduhku berbuat zalim berkenaan dengan hak-hak mereka. Aku benar-benar berlindung kepada Allah dari melakukan kezaliman. Jika aku telah berbuat zalim kepada mereka berkenaan dengan sesuatu yang menjadi milik mereka dan aku memberikannya kepada orang lain, maka benar-benar telah celakalah diriku. Tetapi aku melihat bahwa tidak ada lagi sesuatu (negeri) yang dibebaskan sesudah negeri Khusru (Persia) dan Allah pun telah merampas untuk kita harta kekayaan dan tanah-tanah pertanian mereka. Maka aku bagibagikan semua kekayaan (yang bergerak) kepada mereka yang berhak, kemudian aku ambil seperlima dan aku atur menurut aturan, dan aku sepenuhnya bertanggung jawab atas pengaturan ini. Tetapi aku berpendapat, untuk menguasai tanah-tanah pertanian, aku kenakan pajak atas penggarapnya, dan mereka berkewajiban membayar jizyah sebagai fay' untuk orang-orang Muslim, untuk tentara yang berperang dan anak turun mereka, serta generasi yang datang kemudian. Tahukah kalian pos-pos pertahanan itu? Disana harus ada orang-orang yang tinggal menetap. Tahukah kalian, negeri-negeri besar, seperti Syam, al-Jazirah (Lembah Mesopotamia), Kufah, Basrah, dan Mesir? Semua itu harus diisi dengan tentara dan disediakan perbekalan untuk mereka. Dari mana mereka mendapat perbekalan itu, jika semua tanah pertanian telah habis dibagi-bagi?

Dari kutipan tersebut terlihat bahwa Umar memutuskan untuk menyita dan tidak membagi-bagikan tanah pertanian yang telah ditaklukkan kepada para tentara. Oleh karena itu tindakannya tersebut dipandang menyimpang dari yang dicontohkan Rasul dan hal ini berarti menyimpang juga dari nas (al-Qur'an atau al- 


\section{Ansori}

Sunnah). Namun dari kutipan itu terlihat pula bahwa tindakan Umar bertolak dari suatu pemikiran yang sangat realistis di mana kalau tanah-tanah rampasan itu habis dibagi-bagikan kepada para prajurit, negara akan kesulitan dana untuk membiayai penjagaan pos-pos keamanan. Di samping juga akan terjadi penumpukan kekayaan pada orang-orang tertentu saja.

Jadi, sebagaimana dikemukakan oleh Nurcholis Madjid, tindakan Umar tidak membagi-bagikan harta rampasan perang (yang berupa tanah-tanah pertanian) tersebut sesungguhnya tidaklah melanggar Sunnah Rasul. Umar justru mampu menangkap semangat yang melandasi tindakan Rasul, yakni kemaslabatan atau kepentingan umum. Jika Rasul membagi-bagikan harta rampasan perang kepada orang-orang Muslim dan prajurit perang, tanpa menyisakan untuk generasi sesudahnya, hal itu dikarenakan situasinya memang menghendaki yang demikian, yaitu untuk menolong nasib orang-orang miskin muhajirin dari Makkah yang terusir dari tempat-tempat kediaman dan harta benda mereka. Manakala Umar tidak membagi-bagikan, hal itupun dikarenakan situasi saat itu menghendaki kebijakan demikian.

\section{b. Perceraian yang Dilakukan di Depan Sidang Pengadilan}

Contoh lain dari keputusan atau kebijakan hukum yang didasarkan atas pertimbangan kemaslahatan ini adalah mengenai perceraian yang ada dalam Undang-Undang No. 1 Tahun 1974. Dalam Bab VIII Pasal 39 (1) ditegaskan bahwa: "Perceraian hanya dapat dilakukan di depan Sidang Pengadilan setelah Pengadilan yang bersangkutan berusaha dan tidak berhasil mendamaikan kedua belah pihak." 28

Berdasarkan ketentuan Undang-Undang tersebut perceraian hanya boleh dilakukan dan dianggap sah kalau sudah diputuskan oleh sidang pengadilan. Ketentuan ini tidak lepas dari pertim-

${ }^{28}$ Lihat Undang-Undang Perkaninan (UU No. 1 Tabun 1974) (Surabaya: Pustaka Tinta Mas, t.t.), hal. 16 - 17. 
bangan mengenai situasi dan kondisi masyarakat Indonesia. Tanpa adanya ketentuan tersebut orang akan cenderung sewenang-wenang dalam menjatuhkan talak kepada istrinya sehingga akan berakibat penderitaan, kesengsaraan, dan ketidakmaslahatan dipihak istri, anak, dan mungkin juga bagi sang suami sendiri. Lebih jauh lagi, dengan situasi semacam ini akan semakin membuka kemungkinan munculnya para suami yang tidak bertanggungjawab. Bertolak dari prinsip kemaslahatan seperti inilah, antara lain, kebijakan tentang harusnya perceraian dilakukan di depan sidang peradilan dikukuhkan.

\section{Kesimpulan}

Dari uraian singkat di atas, dapat diambil beberapa kesimpulan sebagai berikut :

1. Fikih merupakan ketetapan hukum yang dihasilkan dari pemahaman terhadap nas (al-Qur'an dan al-sunnah) dan merupakan keputusan hukum yang fungsinya antara lain untuk menyelesaikan masalah-masalah yang muncul, yang tidak secara langsung ketentuan hukumnya disebutkan dalam nas.

2. Oleh karena fikih pada dasarnya merupakan hasil interpretasi dan formulasi para ulama, maka ia sangat terkait dengan, situasi, kondisi, adat, sosial budaya, dan kemampuan intelektual. Dengan kata lain, fikih adalah keputusan hukum yang tidak bisa lepas dari nilai kontekstualitasnya.

3. Salah satu prinsip yang mampu mengantar nilai kontekstualitas fikih adalah prinsip kemaslahatan. Dengan menerapkan prinsip ini fikih senantiasa menjaga agar setiap keputusan hukumnya selalu relevan dengan situasi yang terus berubah namun tetap tidak menyimpang dari jiwa dan pesan umum syari'at Islam. 


\section{DAFTAR PUSTAKA}

Basyir, Ahmad Azhar, MA. "Pokok-Pokok Ijtihad dalam Hukum

Islam," dalam Ijtihad Dalam Sorotan. Bandung: Mizan, 1988.

Departemen Agama RI. Usul Fikih. Proyek Pembinaan Prasarana

Dan Prasarana Perguruan Tinggi Agama Islam, 1986.

Husaini, S. Waqar Ahmad. The Early Development of Islamic Jurispredence, terj. Agah Gunardi. Bandung: Pustaka, 1984.

'Izz al-Din ibn 'Abd al-Salām. Qawa'id al-Aḅkām fi Masălh al-Anäm. Beirut: Dār al-Ma'rifah, t.t.

Ibn al-Qayyim al-Jawziyyah. I'läm al-Munaqqi'īn. Beirut: Dār al-Jil, t.t.

Khallaf, Abdul Wahhab. Ilmu Usul Fikih, terj. Nur Iskandar Albarsany. Bandung: Risalah, 1985.

Madjid, Nurcholis. "Konsep Asbab al-Nuzul: Relevansinya bagi Pandangan Historisis Mengenai Segi-Segi Tertentu Ajaran Keagamaan," dalam Kontekstualisasi Doktrin Islam Dalam Sejarah. Jakarta: Paramadina, 1995.

Al-Qarḍāwi, Yūsuf. Al-Fiqh al-Islämi Bayna al-Așālah wa al-Tajdìd. Beirut: tnp., 1986.

Rahmat, Jalaluddin. "Peranan Tuntunan Situasi Dalam Memahami Hukum Islam," dalam Kontekstualisasi Doktrin Islam Dalam Sejarah. Jakarta: Paramadina, 1995.

Ramaḍān, Muhammad Sa'id. Dawabit al-Maslahah. Bairut: Mu'assasah al-Risālah, 1987.

Sardar, Ziauddin. Islamic Futures The Shapes of Ideas to Come, terj. Rahmani Astuti. Bandung: Pustaka, 1985. 
Kontekstualisasi Fikih Melalui Prinsip Kemaslahatan

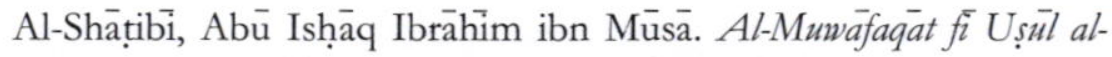
A h̦kāam, 2 jilid. Makkah: Där al-Bāj, t.t.

Wahid, Abdurrahman. "Pengembangan Fikih Yang Kontekstual." Pesantren, 2, 2 (1985).

Yafie, KH. Ali. Menggagas Fiqih Sosial. Bandung: Mizan, 1994.

. 'Konsep-Konsep Istiḥsān, Istișlaḥ, dan Maslahat Al"Ammah," dalam Kontekstualisasi Doktrin Islam Dalam Sejarah. Jakarta: Paramadina, 1995.

Yahya, Mukhtar. Dasar-Dasar Pembinaan Hukum Islam. Bandung: AlMa'arif, 1986.

Zaid, Farouq Abu. Al-Syari'ah al-Islamiyah Baina al-Muhafifidzin wa al-Mujaddidin, terj. H. Husein Muhammad. Jakarta: P3M, 1980.

Zuhdi, Masjfuk. Pengantar Hukum Syari'at. Jakarta: Haji Masagung, 1987.

Undang-Undang Perkawinan (UU No. 1 Tabun 1974). Surabaya: Pustaka Tinta Mas 
Ansori 